\title{
PENYELESAIAN KREDIT MACET PADA KOPERASI SIMPAN PINJAM KARYA ARTHA SEDANA DAN KSP. WIRARTHA UTAMA DIKOTA DENPASAR SELATAN*
}

\author{
Oleh : \\ Ni Luh Anggun Sri Herlina Sari** \\ A.A. Sri Indrawati*** \\ Suatra Putrawan**** \\ Program Kekhususan Hukum Bisnis Fakultas Hukum \\ Universitas Udayana
}

\begin{abstract}
ABSTRAK
Koperasi menepati kedudukan yang sangat terhormat dalam perekonomian Indonesia. Koperasi yang secara etimologi merupakan suatu perkumpulan atau organisasi ekonomi yang beranggotakan orang-orang atau badan yang memberikan kebebebasan masuk dan keluar sebagai anggota. Dengan adanya lembaga yang berbentuk koperasi seperti contoh koperasi simpan pinjam yang menghimpun dana dari para anggotanya kemudian menyalurkan kembali dana tersebut kepada para anggota koperasi dan masyarakat umum dan menimbulkan permasalahan yaitu apa sajakah faktor-faktor yang menyebabkan kredit macet pada Koperasi Simpan Pinjam Karya Artha Sedana dan KSP. Wirartha Utama Di Kota Denpasar Selatan dan bagaimana upaya penyelesaian kredit macet pada Koperasi Simpan Pinjam Karya Artha Sedana dan KSP. Wirartha Utama Di kota Denpasar Selatan.
\end{abstract}

* Makalah ilmiah ini ditulis dan dikembangkan lebih lanjut dari Skripsi yang ditulis oleh Penulis Ni Luh Anggun Sri Herlina Sari atas bimbingan Pembimbing I A.A Sri Indrawati, SH.,MH. Dan Pembimbing II Suantra Putrawan, SH.,MH.

** Ni Luh Anggun Sri Herlina Sari mahasiswi dari Fakultas Hukum Universitas Udayana anggunherlina94@gmail.com.

*** A.A Sri Indrawati, Dosen Fakultas Hukum Universitas Udayana.

**** Suantra Putrawan, Dosen Fakultas Hukum Universitas Udayana. 
Didalam penelitian untuk menyusun jurnal ini mempergunakan jenis penlitian hukum empiris, hukum dikonsepkan sebagai suatu gejala empiris yang dapat diamati dalam kehidupan sehari-hari, jenis pendekatan yang digunakan untuk penulisan jurnal ini menggunakan pendekatan fakta dan pendekatan perundang-undangan, penelitian jurnal ini bersifat deskriptif bertujuan mengambarkan secara tepat ada tidaknya hubungan antara suatu gejala dengan gejala lain yang berkembang dalam masyarakat.

Hasil penelitian menyatakan faktor penyebab terjadinya kredit macet pada Koperasi Simpan Pinjam Karya Artha Sedana dan KSP. Wiratha Utama Di Kota Denpasar Selatan adalah adanya kerugian yang dialami nasabah dalam menjalankan usahanya sehingga membuat debitur mengalami kerugian dan dapat berpengaruh pada pembayaran kredit yang berlangsung, tidak adanya etika baik dari pihak nasabah, adanya peminjaman kredit tetapi tanpa adanya persetujuan dari pihak keluarga, dan dengan sengaja menyalahgunakan peminjaman kredit tersebut. Sedangkan penyelesaian kredit macet pada Koperasi Simpan Pinjam Karya Arha Sedana dan KSP. Wirartha Utama Di Kota Denpasar Selatan yaitu melelui mekanisme pemanggilan yang dilakukan oleh pihak koperasi selaku kreditur bertujuan untuk mengetahui penyebab debitur belum bisa melunasi hutangnya. Dalam perjanjian kredit pada Koperasi Simpan Pinjam Karya Artha Sedana dan KSP. Wirartha Utama Di Kota Denpasar Selatan sebaiknya pihak koperasi lebih maksimal dalam melakukan pengawasan terhadap kreditur agar kredit yang diberikan tidak disalahgunakan oleh debitur.

Kata Kunci : Koperasi, Kredit, Perjanjian

\section{ABSTRACT}

The cooperative kept a very respectable position in the Indonesian economy. Etymologically cooperative is an economic association or organization consisting of people or bodies that provide freedom of entry and exit as members. With the existence of cooperative institutions such as the example of a savings and loan cooperative that collects funds from its members then redistributes the funds to cooperative members and the general public and raises problems namely what are the factors that cause bad credit to the Karya Artha Sedana Savings and Loan Cooperative and KSP. Wirartha Utama in the City of South Denpasar and how the efforts to resolve bad credit at the Karya Artha Sedana Savings 
and Loan Cooperative and KSP. Wirartha Utama in the city of South Denpasar.

In this study to compile this journal using a type of empirical legal research, law is conceptualized as an empirical phenomenon that can be observed in daily life, the type of approach used for writing this journal uses a factual approach and legislative approach, this journal research is descriptive in purpose accurately describe the relationship between a symptom and other symptoms that develop in the community.

The results of the study stated that the causes of the occurrence of bad credit in the Karya Artha Sedana Savings and Loan Cooperative and KSP. Main Wiratha in South Denpasar City is a loss experienced by the customer in running his business, causing debtors to suffer losses and can affect the ongoing credit payments, lack of ethics from the customer, loan lending but without the consent of the family, and with intentionally misusing the loan. While the settlement of bad loans at the Savings and Loan Cooperative by Arha Sedana and KSP. Wirartha Utama in the City of South Denpasar, namely through the mechanism of summons made by the cooperative as the creditor aims to find out the cause of the debtor has not been able to pay off his debt. In the credit agreement at Karya Artha Sedana Savings and Loan Cooperative and KSP. Wirartha Utama In the City of South Denpasar, the cooperative should be more maximal in conducting supervision of creditors so that the credit provided is not misused by the debtor.

Keywords: Cooperative, Credit, Agreement.

\section{Pendahuluan}

\subsection{Latar Belakang Masalah}

Koperasi menepati kedudukan yang sangat terhormat dalam perekonomian Indonesia. Hal ini tidak hanya tampak pada ketegasan sikap Pasal 33 UUD 1945, tapi juga pada Pasal 4 UU No. 25 Tahun 1992 Tentang Perkoperasian. Dalam penjelasan Pasal 33 UUD 1945 misalnya, koperasi jelas-jelas dinyatakan sebagaai bentuk perusahaan yang sesuai dengan sistem perekonomian yang hendak dibangun di Indonesia. Sedangkan dalam Pasal 4 UU No. 25 Tahun 1992 Tentang Perkoperasian, antara lain dikatakan bahwa fungsi koperasi adalah 
untuk mewujudkan dan mengembangkan perekonomian nasional yang merupakan usaha bersama berdasarkan atas asas kekeluargaan dan demokrasi ekonomi. ${ }^{1}$

Ketegasan Pasal 33 UUD 1945 dan Pasal 4 UU No. 25 Tahun 1992 Tentang Perkoperasian itu tentu tidak tanpa alasan. Di satu pihak, kondisi perekonomian Indonesia sudah sejak lama ditandai oleh terjadinya kesengajaan ekonomi. Kesengajaan tidak hanya terjadi antara sektor pertanian dan industri, atau antara perekonomian desa dan kota, tapi juga antara yang miskin dengan yang kaya. Dipihak lain, masyarakat yang tidak mengenal struktur kesengajaan seperti itu.

Penjelasan Pasal 33 Undang-Undang Dasar 1945 menempatkan Koperasi baik dalam kedudukan sebagai sokoguru perekonomian nasional maupun sebagai bagian integral tata perekonomian nasional. Dengan memperhatikan kedudukan Koperasi seperti diatas maka adanya Koperasi sangat berpengaruh dalam perkembangan potensi ekonomi rakyat serta berpengaruh juga dalam kehidupan berdemokrasi masyarakat yang ekonomis.

Konsepsi demikian memdudukan koperasi sebagai badan usaha yang cukup strategis bagi anggotanya dalam mencapai tujuan-tujuan ekonomi yang pada gilirannya berdampak pada masyarakat secara luas. Disamping lembaga lain seperti bank atau pengadilan, koperasi sebagai urat nadi perekonomian bangsa Indonesia. ${ }^{2}$

${ }^{1}$ Dr. Revrisond Baswir, 2013, Koperasi Indonesia, BPFE, Yogyakarta, h.1. 
Koperasi yang secara etimologi merupakan suatu perkumpulan atau organisasi ekonomi yang beranggotakan orang-orang atau badan yang memberikan kebebebasan masuk dan keluar sebagai anggota menurut peraturan yang ada di Indonesia diatur dalam UndangUndang Republik Indonesia Nomor 25 Tahun 1992 tentang Perkoperasian, dengan bekerjasamanya secara kekeluargaan, menjalankan suatu usaha, dengan tujuan mempertinggi kesejahteraan jasmanilah para anggotanya. ${ }^{3}$

Dewasa ini koperasi terus mengembangkan sayap dibidang usahanya untuk mengikuti perkembangan kebutuhan manusia yang tak terbatas. Salah satu bidang usaha koperasi yang dirasakan kian hari semankin dibutuhkan masyarakat adalah masalah simpan pinjam. ${ }^{4}$

Dalam pemberian kredit diperlukan adanya jaminan karena jaminan merupakan salah satu syarat untuk dikabulkannya permohonan atas permintaan kredit, berdasarkan Undang-undang Nomor 10 Tahun 1998 Tentang perubahan Undang-Undang Nomor 7 Tahun 1992 Tentang Perbankan, sebagaimana yang disebutkan dalam Pasal 11 yang menetapkan suatu jaminan dalam pemberian kredit yang berbunyi yaitu

2 G. Kartasapoetra dan A.G Kartasapoetra dan Kawan, 2001, Koperasi Indonesia yang berdasarkan Pancasila dan UUD 1945, PT Rineka Cipta, Jakarta, h. 11 .

3 Sutantyo Rahardja Hadikusuma, 2009, Hukum Koperasi Indonesia, PT Rajagrafindo Persada, Jakarta, h.1.

${ }^{4}$ Partadiredja Atje, 2000, Manajemen Koperasi, Bharata, Jakarta, h. 3. 
"Bank Indonesia menetapkan ketentuan mengenai batas maksimum pemberian kredit atau pembiayaan berdasarkan prinsip syariah, pemberian jaminan, penetapan investasi surat berharga atau hal lain yang serupa, yang dapat dilakukan oleh bank kepada peminjam atau sekelompok peminjam yang terkait, termasuk kepada perusahaan-perusahaan dalam kelompok yang sama dengan bank yang bersangkutan".

Dari ketentuan pasal tersebut nampak jelas bahwa, jaminan sangat penting dalam pembelian kredit dan juga suatu keharusan dalam upaya untuk menghindari faktor-faktor yang menyebabkan terjadinya hambatan atau masalah yang tidak diinginkan dalam pelaksanaan pemberiian kreditnya, oleh karena itu perlu unsur pengamanan dalam pengembaliannya.

Dalam praktek di Koperasi Artha Sedana dan KSP. Wirartha Utama salah satu masalah yang dihadapi adalah masalah kredit macet. Menghindari dari masalah kredit macet. Jika terjadi kredit macet maka diperlukan penyelesaiannya.

Penulisan ini mengkaji kebolehan terhadap "Penyelesaian Kredit Macet Pada Koperasi Simpan Pinjam Karya Artha Sedana dan KSP. Wirartha Utama di Kota Denpasar Selatan".

\subsection{Rumusan Masalah}

Berdasarkan uraian dari latar belakang yang telah dikemukakan diatas, dapat dikemukakan permasalahan sebagai berikut :

1. Apa sajakah faktor-faktor yang menyebabkan kredit macet pada Koperasi Simpan Pinjam Karya Artha Sedana dan KSP. Wirartha Utama di Kota Denpasar Selatan. 
2. Bagaimana upaya penyelesaian kredit macet pada Koperasi Simpan Pinjam Karya Artha Sedana dan KSP. Wirartha Utama di Kota Denpasar Selatan.

\subsection{Tujuan Penelitian}

Adapun tujuan khusus dari penelitian dan penulisan karya ilmiah ini adalah untuk memahami faktor-faktor penyebab kredit macet dan upaya penyelesaian kredit macet pada Koperasi Simpan Karya Artha Sedana dan KSP. Wirartha Utama Pinjam di Kota Denpasar Selatan.

\section{Isi Makalah}

\subsection{Metode Penelitian}

Didalam penelitian untuk menyusun jurnal ini mempergunakan jenis penelitian hukum empiris. Dalam penelitian empiris, hukum dikonsepkan sebagai suatu gejala empiris yang dapat diamati dalam kehidupan sehari-hari. Dalam konteks ini hukum tidak semata-mata dikonsepkan sebagai suatu gejala normatif yang otonom, sebagai ius contituendum dan tidak pula sebagai ius contituentum, akan tetapi secara empiris sebagai ius operatum.

\subsection{Hasil Penelitian Dan Pembahasan}

\subsubsection{Penyebab Kredit Macet Pada Koperasi Simpan Pinjam Karya Artha Sedana dan KSP. Wirartha Utama Di Kota Denpasar Selatan}

Kredit dalam dunia perbankan dapat didefinisikan sebagai penyedian uang atau tagihan yang dapat dipersamakan dengan itu, berdasarkan persetujuan atau kesepakatan pinjam-meminjam untuk 
melunasi hutangnya setelah jangka waktu tertentu dengan jumlah bunga, imbalan atau pembagian hasil keuntungan.

Terdapat Perjanjian dalam melakukan suatu pinjaman kredit. Perjanjian adalah suatu peristiwa dimana seseorang berjanji kepada orang lain atau dimana dua orang itu saling berjanji untuk melakukan sesuatu hal. 5

Secara umum faktor-faktor yang menyebabkan terjadinya kredit macet pada koperasi adalah :

1. Faktor internal merupakan faktor penyebab kredit macet yang berasal dari kesalahan pihak bank itu sendiri. Penyebab tersebut berasal dari :

a. Kurangnya ketelitian dari pihak bank dalam memberikan kredit kepada setiap nasabah.

b. Lemahnya system informasi dan pengawasan dalam mengajukan kredit.

c. Adanya campur tangan yang berlebih dalam mengambil keputusan kredit. Seperti halnya campur tangan dari pihak koperasi atas dasar kekerabatan.

d. Pengikatan jaminan kredit tanpa adanya jaminan yang cukup.

e. Ketidakmampuan dalam manajemen pecatatan di dalam koperasi yang menyebabkan kegagalan yang terjadi di dalam koperasi tersebut.

${ }^{5}$ R Subekti, 1990, Hukum Perjanjian, Cet.12 (selanjutnya disebut R Subekti 1,) PT. Intermasa Jakarta,(selanjutnya disingkat R Subekti I), h.1 
2. Faktor ekternal merupakan faktor penyebab kredit macet yang berasal dari pihak nasabah.

a. Kegiatan ekonomi dan tingginya suku bunga kredit terjadinya krisis moneter mempunyai dampak yang luas terhadap kegiatan ekonomi terutama pada sektor-sektor usaha disamping masih relatif tingginya tingkat bunga sebagai akibat terjadinya likuidasi di pasar yang menyebabkan terpaksa menaikan suku bunga kredit.

b. Pemanfaatan iklim dunia perbankan yang tidak sehat oleh nasabah yang tidak bertanggung jawab, hal ini sering kali dimanfaatkan oleh beberapa nasabah dengan cara tertentu, sehingga mendorong koperasi untuk mengabaikan prinsipprinsip pemberian kredit yang sehat.

c. Adanya musibah yang menimpa nasabah/perusahaan nasabah, beberapa kredit bermasalah disebabkan karena adanya nasabah yang mendapatkan musibah seperti kematian, kebakaran pada tempat usahanya, pencurian, maupun hal-hal lain yang bersifat musibah.

Faktor yang sering menjadi penyebab terjadinya kredit macet pada Koperasi Simpan Pinjam Karya Artha Sedana tersebut cenderung disebabkan oleh faktor nasabah yaitu :

1. Adanya kegagalan/musibah yang menimpa perusahaan/usaha nasabah sehingga membuat debitur menjadi rugi dan secara langsung berpengaruh terhadap pembayaran kredit yang sedang berlangsung karena apabila nasabah mengalami 
kegagalan/musibah memyebabkan pendapatan debitur menjadi berkurang yang disebabkan oleh tanggungan beban kerugian.

2. Tidak adanya itikat baik dari pihak nasabah sehingga menyebabkan tidak lancar pembayaran kredit. Masih ada beberapa nasabah yang bersifat seperti ini, melihat pembayaran awalnya baik-baik saja namun setelah bulan berikutnya tidak ada pembayaran selanjutnya.

3. Adanya pinjaman kredit tanpa sepengetahuan pihak keluarga/kerabat. Hal ini terjadi karena adanya nasabah yang mengajukan kredit dengan jaminan namun tanpa sepengetahuan keluarga/kerabat, sehingga menyebabkan perselisihan pada keluarga/kerabat tersebut dengan nasabah.

4. Adanya penyalahgunakan kredit oleh nasabah. Hal ini terjadi karena apa yang menjadi tujuan untuk diberikannya kredit tidak sesuai dengan kenyataannya.

Sedangkan faktor yang sering menjadi penyebab terjadinya kredit macet pada KSP. Wirartha Utama tersebut cenderung disebabkan oleh nasabah yaitu Faktor-faktor ini berasal dari sudut eksternal maupun internal, faktor yang bersifat eksternal tersebut adalah keadaan perekonomian dari debitur yang tidak mendukung perkembangan usahanya, disuatu sisi debitur memiliki etikat baik untuk membayarnya dan dikarenakan pula usaha debitur mengalami suatu musibah misalnya debitur mengalami sakit atau kebakaran, hal ini dapat mempengaruhi kualitas kredit atau menyebabkan kredit bermasalah, selain itu faktor yang bersifat internal tersebut dikarenakan pada umumnya pihak analisis kurang teliti sehingga apa yang seharusnya terjadi tidak diperhitungkan sebelumnya. 
Dapat disimpulkan bahwa dari beberapa faktor hambatan yang terjadi dalam pelaksanaan perjanjian kredit, yaitu salah satunya adanya kredit macet yang disebabkan karena debitur yang wanprestasi, wanprestasi adalah tidak dilaksanakannya prestasi atau kewajiban sebagaimana mestinya yang dibebankan kontrak terhadap pihak-pihak tertentu seperti yang dimaksudkan dalam kontrak yang bersangkutan. ${ }^{6}$

Dari hasil kedua Koperasi Simpan Pinjam di atas dapat dianalisa bahwa ada sedikitnya kesalahan kecil dalam pemberian kredit yang kadang dilakukan oleh petugas bagian kredit hal tersebut adalah :

1. Kurangnya informasi nasabah sebagai peminjam kredit, hal ini cenderung menjadi penyebab terjadinya kredit bermasalah karena informasi nasabah sangatlah penting, dengan adanya informasi nasabah yang lengkap maka dapat memberi informasi secara jelas dimana debitur itu menetap, berasal dan bekerja. Dengan itu akan dapat meminimalisir nasabah yang ingin mempunyai itikad yang tidak baik, seperti lari dari tanggung jawab pindah tempat tinggal agar tidak dijumpai oleh petugas bagian kredit untuk menagih angsuran kreditnya.

2. Kurang ketelitian petugas lapangan dalam menganalisa kredit menyebabkan beberapa nasabah menjadi kurang lancar dalam membayar angsuran mereka, dikarenakan nominal pembayaran pinjaman dengan penghasilan dari nasabah tersebut tidak singkron.

${ }^{6}$ Munir Fuandy, 2001, Hukum Kontak (dari Sudut Pndang Hukum Bianis), PT. Citra Aditya Bakti, Bandung, h.87. 
3. Masih eratnya sistem hubungan kekeluargaan/kerabat, hal ini menjadi salah satu penyebab terjadinya kredit yang bermasalah di koperasi ini, karena banyak sanak keluarga maupun kerabat dekat dari para pejabat koperasi maupun petugas lapangan diwakili mereka untuk melakukan pinjaman kredit. Meskipun nominal pinjaman tersebut dikatakan tidak banyak dan memiliki tujuan yang jelas, tetap saja dalam pembayaran angsuran ada saja yang tidak lancar, bahkan hanya melakukan pembayaran bunga saja.

\subsubsection{Penyelesaian Kredit Macet Pada Koperasi Simpan Pinjam Karya Artha Sedana dan KSP. Wirartha Utama Di Kota Denpasar Selatan}

Adanya kredit bermasalah apabila macet yang menjadi beban bagi koperasi menjadi salah satu indikator penentu kinerja koperasi, oleh karena itu adanya kredit bermasalah apabila macet memerlukan penyelesaian yang cepat, tepat dan akurat dan memerlukan tindakan penyelamatan dan penyelesaian dengan segara. Tindakan koperasi dalam usaha menyelamatkan dan menyelesaikan kredit macet akan sangat bergantung pada kondisi kredit bermasalah apabila macet itu sendiri. Untuk menyelamatkan dan menyelesaikan kredit macet ada dua strategi yang ditempuh.

Upaya yang dilakukan Koperasi Simpan Pinjam Karya Artha Sedana apabila terjadi kredit bermasalah yaitu melalui mekanisme pemanggilan, pemanggilan tersebut dilakukan pihak koperasi selaku kreditur bertujuan untuk mengetahui faktor apa yang menyebabkan debitur belum dapat melunasi hutangnya, dengan melakukan dialog 
antara kreditur dengan debitur. Sehingga dengan demikian akan tercipta suatu solusi yang terbaik dalam menyelesaikan masalah. Dan bagi kredit bermasalah yang tidak dapat diselesaikan atau ditagih kembali setelah dilakukan upaya penyelesaian tersebut, maka satuan kerja (kepala bagian kredit) mengusulkan cara-cara penyelesaian kredit yang sudah tidak dapat ditagih kepada pengurus dengan cara melalui negosiasi, yaitu kredit yang tadinya bermasalah atau macet diadakan kesempatan baru sehingga terhindar dari masalah. Bentuk negosiasi penyelamatan kredit bermasalah, seperti penyusunan kembali syarat-syarat kredit, yakni sebagai berikut :

1. Rescheduling (Penjadwalan Ulang) Yaitu perubahan syarat kredit hanya menyangkut jadwal pembayaran dan atau jangka waktu temasuk masa tenggang (grace period) dan perubahan besarnya angsuran kredit. Tentu tidak kepada semua debitur dapat diberikan kebijakan ini, melainkan hanya kepada debitur yang menunjukkan itikad dan karakter yang jujur dan memiliki kemauan untuk membayar atau melunasi kredit (willingness to pay).

2. Reconditioning (Persyaratan Ulang) Yaitu perubahan sebagian atau seluruh syarat-syarat kredit yang tidak terbatas pada perubahan jadwal pembayaran, jangka waktu, tingkat suku bunga, penundaan pembayaran sebagian atau seluruh bunga dan persyaratan lainnya. Perubahan syarat kredit tersebut tidak termasuk penambahan dana atau injeksi dan konversi sebagian atau seluruh kredit menjadi equity perusahaan.

3. Restructuring (Penataan Ulang)

Yaitu perubahan syarat kredit yang menyangkut : 
a. Penambahan dana

b. Konversi seluruh atau sebagian tunggakan bunga menjadi pokok kredit baru

c. Konversi seluruh atau sebagian dari kredit menjadi penyertaan bank atau mengambil partner yang lain untuk menambah penyertaan

4. Liquidation (Liquidasi) Yaitu penjualan barang-barang yang dijadikan jaminan dalam rangka pelunasan utang. Pelaksanaan likuidasi ini dilakukan terhadap kategori kredit yang memang benar-benar sudah tidak dapat dibantu lagi untuk disehatkan kembali atau usaha nasabah yang sudah tidak memiliki prospek untuk dikembangkan.

Sedangkan upaya yang dilakukan KSP Wirartha Utam apabila terjadi kredit bermasalah antara lain:

1. Dengan cara negosiasi datang kerumahnya untuk bertanya kenapa belum membayar kredit yang dipinjam.

2. Jika sudah jatuh tempo pihak koperasi berhak untuk mengambil barang/kendaraan sesuai yang dijaminkan dikoperasi.

3. Jika barang/kendaraan yang dijaminkan tidak ada, pihak debitur memberi barang/kendaraan yang lain sesuai total hutang yang dipinjam untuk diberikan kepihak koperasi untuk mengganti barang/kendaraan yang dijaminkan sudah tidak ada lagi tetapi, sebelum barang pengganti diberikan pihak koperasi akan membuat surat hitam diatas putih.

4. Apabila cara diatas tidak dapat terlaksana dengan baik maka dapat dilakukan dengan jalur hukum. 
Dari pendapat hasil wawancara dikedua Koperasi Simpan Pinjam dapat dianalisa bahwa upaya penyelesaian kredit bermasalah atau macet yang terjadi di dalam koperasi yaitu setiap koperasi memiliki upaya yang sama apabila terjadi kredit macet tersebut. Berbagai upaya tersebut adalah melakukan suatu pemanggilan terhadap debitur yang belum melunasi kreditnya, melakukan suatu negosiasi atau musyawarah terhadap debitur tersebut agar mendapatkan jalan keluar dan apabila tidak mendapatkan solusi ataupun jalan keluarnya maka dapat dilanjutkan ke jalur hukum.

\section{Penutup}

\subsection{Kesimpulan}

Berdasarkan dari uraian dan pembahasan diatas, maka dapatlah ditarik kesimpulan yang menjadi faktor yang menyebabkan terjadinya kredit macet pada koperasi simpan pinjam Karya Artha Sedana dan KSP. Wirartha Utama dikota denpasar selatan adalah adanya kegagalan atau musibah yang menimpa perusahaan atau usaha nasabah sehingga membuat debitur menjadi rugi dan secara langsung berpengaruh terhadap pembayaran kredit yang sedang berlangsung, tidak adanya itikat baik dari pihak nasabah sehingga menyebabkan tidak lancar pembayaran kredit, adanya pinjaman kredit tanpa sepengetahuan pihak keluarga/kerabat, adanya penyalahgunakan kredit oleh nasabah. dan upaya penyelesaian kredit macet pada koperasi simpan pinjam karya artha sedana dan KSP. Wirartha utama dikota denpasar selatan yaitu diberikan peringatan, musyawarah untuk menyelesaikan kredit macet debitur dengan cara 
melalui mekanisme pemanggilan yang dilakukan Pihak Koperasi selaku Kreditur bertujuan untuk mengetahui faktor apa yang menyebabkan debitur belum dapat melunasi hutangnya, jika sudah jatuh tempo pihak koperasi berhak untuk mengambil barang/kendaraan sesuai yang dijaminkan dikoperasi.

\subsection{Saran}

Berdasarkan kesimpulan diatas dapat disarankan sebagai berikut :

1. Dalam perjanjian kredit pada koperasi simpan pinjam Karya Artha Sedana dan KSP Wirartha Utama di Kota Denpasar Selatan, sebaiknya pihak koperasi lebih maksimal dalam melakukan pengawasan terhadap kreditur agar kredit yang diberikan tersebut tidak disalahgunakan oleh debitur.

2. Kepada debitur hendaknya mentaati aturan-aturan yang ada atau melaksanakan perjanjian dengan kesepakatan sebaikbaiknya demi menjaga nama baik, sehingga dipercaya di kemudian hari agar tetap diberikan kepercayaan oleh koperasi.

\section{DAFTAR PUSTAKA}

Atje, Partadiredja, 2000, Manajemen Koperasi, Penerbit Bharata, Jakarta.

Dr. Revrisond Baswir, 2013, Koperasi Indonesia,BPFE, Yogyakarta.

Kartasapoetra, G dan A. G Kartasanaoetra dan kawan, 2001, Koperasi Indonesia yang Berdasarkan Pancasila dan UUD 1945. PT Rineka Cipta, Jakarta. 
Munir Fuandy, 2001, Hukum Kontak (dari Sudut Pndang Hukum Bianis), PT. Citra Aditya Bakti, Bandung.

R Subekti, 1990, Hukum Perjanjian, Cet.12 (selanjutnya disebut R Subekti 1,) PT. Intermasa Jakarta,(selanjutnya disingkat $\mathrm{R}$ Subekti I).

Sutantyo Rahardja Hadikusuma, 2009, Hukum Koperasi Indonesia, PT. Raja Grafindo Persada, Jakarta.

\section{PERATURAN PERUNDANG-UNDANGAN}

Undang-Undang Dasar Negara Republik Indonesia Tahun 1945.

Undang-Undang Republik Indonesia Nomor 25 Tahun 1992 Tentang Perkoperasian.

Undang-Undang Republik Indonesia Nomor 10 Tahun 1998 Tentang Perbankan.

Kitab Undang-Undang Hukum Perdata, 1992, Subekti dan Tjitro Sudibyo, PT. Pradnyagama, Jakarta.

\section{JURNAL ILMIAH}

Ni Luh Dery Suanjani, 2018, "Penyelesaian Kredit Macet. Dengan Jaminan Fidusia Berupa Piutang Fiktif", Kertha Semaya Vol. 6, No. 5, https://ojs.unud.ac.id/index.php/kerthasemaya/article/view/4384 $\underline{5}$, diakses tanggal 13 juni 2019, Pukul 18.26 WITA

Anak Agung Intan Wulan Sari, 2018, "Pelaksanaan Perjanjian Kredit Jaminan Perorangan Terkait Debitur Wanprestasi Pada Bank Perkreditan Rakyat", Kertha Semaya Vol.6, No. 5, https://ojs.unud.ac.id/index.php/kerthasemaya/article/view/4358 $\underline{0}$, Diakses 13 juni 2019, Pukul 18.26 WITA 